\title{
Effect of Irrigation and Nutrient Management on Growth, Quality, Yield and Water Productivity of Bitter Gourd in Humid Subtropical Climate
}

\author{
Subam Khawas ${ }^{1 *}$, Anirban Bhowmik ${ }^{1}$, Ratneswar Ray ${ }^{1}$ and Sanmay Kumar Patra ${ }^{2}$ \\ ${ }^{1}$ Department of Soil and Water Conservation, ${ }^{2}$ Department of Agricultural Chemistry and Soil \\ Science, Bidhan Chandra Krishi Viswavidyalaya, Mohanpur- 741 252, West Bengal, India
}

*Corresponding author

\section{A B S T R A C T}

Keywords

Irrigation

frequency,

Balanced nutrients,

Fruit yield, Water

productivity, Bitter gourd

\section{Article Info}

Accepted:

10 August 2020

Available Online:

10 September 2020
The field experiment was conducted on a sandy clay loam soil during summer season of 2018 at the Instructional Farm, Bidhan Chandra Krishi Viswavidyalaya, Jaguli lying in indo-Gangetic plains of West Bengal under humid subtropical climate to study the effect of three frequencies of irrigation at 7, 10 and 15 days interval and four nutrient management viz., $100 \%$ RDF, 75\% RDF + biofertilizer, FYM + biofertilizer and 50\% $\mathrm{RDF}+\mathrm{FYM}+$ biofertilizers on growth, yield attributes and fruit yield bitter gourd (Momordica charantia L.) cv. Pusa vishesh. The results of the study showed that the seasonal crop evapotranspiration with maximum yield potential was $479.6 \mathrm{~mm}$. Individual application of moderate frequency of irrigation at 10 day interval or 50\% RDF + FYM @ $15 \mathrm{t} / \mathrm{ha}+$ bio-fertilizers recorded the highest number of vines per plant, maximum vine length, length of internodes, number of fruits per plant, fruit length, fruit girth, flesh thickness of fruit, fruit weight per plant and fruit yield. The coupling effect revealed that moderate frequency of irrigation at 10 days interval along with balanced nutrients application through 50\% RDF (30:20:20 kg NPK/ha) + FYM + bio-fertilizers inoculation was found to be the best treatment combination for deriving maximum growth characters, yield augmenting parameters, fruit yield (17.79 t/ha) and moderate crop water productivity $\left(3.71 \mathrm{~kg} / \mathrm{m}^{3}\right)$ which might be advocated to the resource poor farm regions. The developed predictive model on water-yield production function can serve as a good guideline for bitter gourd growers to yield potential allocation decision related to varying irrigation water supply.

\section{Introduction}

Bitter gourd (Momordica charantia L.) is one of the leading summer vegetable crops of the cucurbitaceous family. It is extensively cultivated in tropical and sub tropical regions of the world. It is popularly known as bitter melon, karaila, or balsam pear. It is widely grown in India, Pakistan, China, Indonesia, Malaysia and Singapore and other South Asian countries. India is the largest producer of bitter gourd producing $31 \%$ of the total world's production while China producing 22\% (Asraf et al., 2019). The leading bitter gourd producing states in our country are Uttar Pradesh, Odisha, Maharashtra, Andhra 
Pradesh, Madhya Pradesh, Gujarat, Chhattisgarh, West Bengal, Bihar, Tamil Nadu and Kerala (Thriveni et al., 2015). In India, it is grown in an area of 99 thousand hectare with a production of 1204 thousand metric tonnes (NHB, 2018-19). The crop is mainly cultivated for its fruits that are rich sources of minerals like iron, phosphorus and potassium, vitamin $\mathrm{A}, \mathrm{B}$ and $\mathrm{C}$, proteins and antioxidant such as beta carotene (Trivedi et $a l$, 2011). The fruit is laxative and easily digestible besides having herbicidal property. The fruits have medicinal values and are very useful for health by virtue of its disease preventing and health promoting phytochemical compounds. It is good for curing blood diseases, rheumatism, diabetes and asthma (Grover and Yadav, 2004).

Among the several environmental factors associated with vegetable production, water and nutrient are considered to be limiting natural resources which affect the growth, quality and yield of vegetable crops. The adequate availability or judicious use of irrigation water in the rhizosphere during critical growth stages of crop is imperative for sustainable growth and production. Soil water excess or stress in any physiological stage markedly inhibits the metabolism and rate of photosynthesis leading to depressed yield (Zimmermann et al., 1988; Hari and Girija Devi, 2016). The irrigation water should be carefully managed with higher efficiency and maximum utility to obtain higher production and productivity of vegetable crops. The role of irrigation at appropriate level matching with the crop growth stage has great significance in improving yield (Singh et al., 1990). Under limited water availability, controlled irrigation scheduling is widely practiced as a critical deficit irrigation management strategy to combat the soil water stress in root zone proximity at its critical growth stages with higher water use efficiency and has higher degree of adaptability at the farmers' level due to simplicity of handling the technique (Kumar and Senseba, 2008; Himanshu et al., 2013). Adequate and appropriate water supply is essential not only for stable and profitable yield of crop but also for marketable quality.

Nutrient management is another factor of prime consideration for achieving higher crop yield. The vegetable crops being annual and short duration in nature are the heavy feeders of plant nutrients. Plenty supply of nutrients are essentially required to ensure proper growth and higher production. The continuous use of chemical fertilizers has a potential threat to the environment in relation to soil, air and groundwater pollution (Oad et al., 2004). In view of increasing cost of synthetic mineral fertilizers, the organic manures like cattle and poultry manures can be partially substituted to mitigate the crop nutritional demand and to curtail the cost on the investment of expensive chemical fertilizers (Rodríguez et al., 2008). The bulky organic manures provides slow release of nutrients to plants, incorporates organic matter to soil that improves soil physical, chemical and biological properties of soil like soil structure, nutrient retention, aeration, soil moisture holding capacity and water infiltration and releases growth promoting substances (Samman et al., 2008).

The balanced nutrient management through mineral fertilizer, organic manure and biofertilizer is an alternative viable option to enhance the yield and crop quality, besides improving soil health and economic profitability (Rani and Mallareddy, 2007; Wailare, 2014). The acceptance or rejection of any adoptable technology to the farming community is primarily dependent on its procedural approach and high monetary returns in terms of net returns and benefit-cost ratio. 
In the Indo-Gangetic plains of West Bengal, bitter gourd is a commercial and remunerative vegetable crop due to its delicious taste, high nutritional and medicinal values and good marketable returns. The farmers usually grow the crop with conventional surface irrigation with improper nutrition resulting in low yield and poor quality of produce. As the crop is very responsive to the availability of water and nutrients in soil, the injudicious application may affect their performance. Standardization of these inputs is thus prerequisite under specific soil, crop and climatic conditions before advocating to the farming community and other stakeholders for large scale adoption. Keeping all these points in view, the present investigation was carried out with the objectives of finding out the response of bitter gourd to different irrigation schedules and nutrient management for obtaining higher yield, quality and water productivity under field condition.

\section{Materials and Methods}

The field experiment was conducted during summer season of 2018 on bitter gourd at the Instructional Farm, Bidhan Chandra Krishi Viswavidyalaya, Jaguli, Nadia in jurisdiction of indo-Gangetic plains of West Bengal under humid subtropical climate. The site is geographically located at $22^{0} 93^{\prime} \mathrm{N}$ latitude and $88^{0} 53^{\prime} \mathrm{E}$ longitude with an average altitude of $9.75 \mathrm{~m}$ above mean sea level. The experimental soil is sandy clay loam in texture and medium in soil fertility with good drainage and water transmission characteristics. The physical, hydro-physical and chemical properties of the soil are furnished in Tables 1 and 2. The climatological parameters during the cropping period are illustrated in Fig. 1. The treatments consisted of three frequencies irrigation $(7,10$ and 15 days interval) assigned in main factors and four nutrient management (100\% RDF, 75\% RDF + biofertilizer @ 2 kg/ha, FYM @
15 t/ha + biofertilizer @ 2 kg/ha and 50\% RDF+FYM@15 t/ha + biofertilizer@2 $\mathrm{kg} / \mathrm{ha}$ ) allotted in sub-factors were laid out in a split-plot design with three replications. The treatment combinations were assigned randomly to the experimental units in each block. The net plot size for each experimental unit was $3 \mathrm{~m} \times 2 \mathrm{~m}$ with $60 \mathrm{~cm}$ width irrigation channel in between replication. The recommended dose of fertilizers used in the experiment was $60: 40: 40:: \mathrm{N}: \mathrm{P}_{2} \mathrm{O}_{5}: \mathrm{K}_{2} \mathrm{O} \mathrm{kg} / \mathrm{ha}$ in the form of urea, single superphosphate and muriate of potash, respectively. Full $\mathrm{P}_{2} \mathrm{O}_{5}$ and $\mathrm{K}_{2} \mathrm{O}$ and half of $\mathrm{N}$ as per prescribed treatment schedules were applied as basal and the remaining $\mathrm{N}$ was top dressed in two equal splits at 30 and 45 days after sowing, respectively. The fertilizers were mixed up thoroughly and placed at $3-4 \mathrm{~cm}$ below the seed to avoid the direct contact of seeds with fertilizers. The calculated amount of farmyard manure@15 t/ha and biofertilizer viz. azotobacter and azospirillum strain each @ 1 $\mathrm{kg} / \mathrm{ha}$ was incorporated in the selected treatments and mixed meticulously with the soil. After manuring, chemical and bio fertilization, four to five sprouted seeds of bitter gourd variety Pusa vishesh were sown at a spacing of $1.5 \mathrm{~m} \times 1.0 \mathrm{~m}$ on 8 March 2018 in the hills at about $5 \mathrm{~cm}$ depth and covered with the soil to protect the germinating seeds from bird damage. Thinning was done two weeks later to maintain two healthy seedlings per hill and plant population of eight per unit plot. The standard agronomic and plant protection measures were followed uniformly. Four vines from each plot were randomly selected for recording the growth parameters viz., number of branches per plant, length of branches per plant and length of internodes and yield contributing parameters viz., number of fruits per plant, fruit weight, length of fruit, girth of fruit, fruit flesh thickness, fruit yield per plant and per hectare at first harvest on 6 May 2018. The fruit was 
harvested manually in 4-5 pickings when the fruits were fully matured. The total crop duration from sowing to final harvesting was 98 days.

Irrigation water was applied at 7 days $\left(\mathrm{I}_{1}\right), 10$ days $\left(\mathrm{I}_{2}\right)$ and 15 days $\left(\mathrm{I}_{3}\right)$ interval in furrow in the selected plots. About 11, 7 and 5 number of irrigation at $50 \mathrm{~mm}$ depth each was adopted in irrigation frequency of $\mathrm{I}_{1}, \mathrm{I}_{2}$ and $\mathrm{I}_{3}$, respectively. At the time of sowing, a lighter irrigation at $20 \mathrm{~mm}$ depth was initially given to each unit plot for proper and uniform seed germination and maintaining identical irrigation regime of the experimental field. Thereafter the irrigation was started on 15 March 2018 and continued up to 25 May 2018.

Seasonal crop water use or actual crop evapotranspiration (ETa) during the growing period (sowing to harvest) from the bitter gourd field was computed using the onedimensional soil water balance equation (Simsek et al., 2005) as below,

$$
\mathrm{ETa}=\mathrm{I}+\mathrm{P} \pm \Delta \mathrm{SW}-\mathrm{Dp}+\mathrm{Wg}-\mathrm{Rf}
$$

where, I is the amount of irrigation water applied $(\mathrm{mm}), \mathrm{P}$ is the precipitation $(\mathrm{mm})$, $\pm \Delta \mathrm{SW}$ is the change in soil water storage in the $0-60 \mathrm{~cm}$ depth of soil profile between sowing and harvest (mm), Dp is the deep percolation $(\mathrm{mm}), \mathrm{Wg}$ is the amount of water used by crop through capillary rise from groundwater $(\mathrm{mm})$, and $\mathrm{Rf}$ is the amount of runoff $(\mathrm{mm})$. The runoff (Rf) and deep percolation (Dp) were assumed to be negligible as the amount of irrigation water applied was managed carefully to prevent over irrigation or runoff. The capillary rise from groundwater $(\mathrm{Wg})$ was assumed to be negligible as depth of groundwater table was 10-12 m below ground level. The amount of effective rainfall $(\mathrm{Re})$ was calculated by deducting deep percolation (Dp) from precipitation (P). Thus, $\mathrm{ETa}=\mathrm{I}+\mathrm{Re} \pm \Delta \mathrm{SW}$.
Crop water productivity (CWP) is the ratio of fresh fruit yield obtained for each treatment to the amount of water depleted by the crop in the process of evapotranspiration and was calculated by the relationship proposed by Kang et al., (2000) as, CWP $\left(\mathrm{kg} / \mathrm{m}^{3}\right)=$ Y/ETa

Where, $\mathrm{Y}=$ fresh fruit yield $(\mathrm{kg} / \mathrm{ha}), \mathrm{ETa}=$ actual crop evapotranspiration $\left(\mathrm{m}^{3} / \mathrm{ha}\right)$

The growth, yield components and fruit yield data obtained for different treatments were subjected to analysis of variance and statistical significance between means of individual treatments was compared using the least significant difference (LSD) test at $p$ $<0.05$ (Gomez and Gomez, 1984).

\section{Results and Discussion}

\section{Growth characteristics, yield components and fruit yield}

The growth characteristics, yield components and fruit yield of bitter gourd were significantly affected by the individual or combined effects of different irrigation frequencies and nutrient management with a few exceptions (Table 3). However, highest number of vines per plant (6.62), maximum vine length $(77.6 \mathrm{~cm})$, greatest length of internodes $(3.61 \mathrm{~cm})$, highest number of fruits per plant (13.21), maximum fruit length $(10.86 \mathrm{~cm})$, highest fruit girth $(3.37 \mathrm{~cm})$, maximum flesh thickness of fruit $(7.54 \mathrm{~mm})$, highest fruit weight per plant $(0.76 \mathrm{~kg})$ and maximum fruit yield (16.94 t/ha) were obtained with moderate frequency of irrigation at 10 day interval $\left(I_{2}\right)$ which were superior over irrigation frequency at 7 day interval $\left(\mathrm{I}_{1}\right)$ and 15 day interval $\left(\mathrm{I}_{3}\right)$ except fruit girth where all irrigation treatments were statistically at par. Higher frequency of irrigation $\left(\mathrm{I}_{1}\right)$ recorded significantly the lowest growth characteristics, yield components and fruit yield while lower 
frequency of irrigation $\left(\mathrm{I}_{3}\right)$ displayed the moderate growth characteristics, yield components and fruit yield. This revealed to the fact that imposition of optimum soil water availability as a result of moderate irrigation frequency $\left(\mathrm{I}_{1}\right)$ on regular basis had positive impact on the growth, yield contributing parameters and yield, while higher $\left(\mathrm{I}_{1}\right)$ or lower frequency of irrigation $\left(I_{3}\right)$ had negative or detrimental effects on growth, yield constituents and yield due to soil water excess or soil water stress, respectively. Optimum water availability in soil might have encouraged the water and nutrients absorption as a result of increasing root growth and proliferation due to greater root zone aeration, increasing microbial activities and many biochemical and enzymatic reactions in soil, more production of photosynthates and its translocation in different plant parts which eventually hastened the growth, yield attributes and fruit yield. On the contrary, the deficit irrigation regime due to lower frequency of irrigation $\left(\mathrm{I}_{3}\right)$ might have failed to fulfill the crop water requirement possibly due to high soil water stress which restricts transpiration, stomatal opening and reduced ${ }^{14} \mathrm{CO}_{2}$ fixation resulting in low photosynthetic activity, retarded growth and expansion of leaf area resulting in depressed yield (Nemeskéri and Helyes, 2019).

This amply indicates that maintenance of optimum irrigation supply all through the growth stages is imperative in increasing the yield, probably due to better water and nutrient distribution and utilization by plant and excellent soil-water-air relationship with higher oxygen concentration in the root zone (Acar et al., 2008).

The results are in consonance with the findings of Samsad et al., (2019) who achieved the optimum growth and yield performance of bitter gourd by irrigation at 10 days interval.
Likewise, the integrated application of 50\% $\mathrm{RDF}+\mathrm{FYM}+$ bio-fertilizers $\left(\mathrm{N}_{4}\right)$ recorded highest number of vines per plant (6.10), maximum vine length $(81.99 \mathrm{~cm})$, greatest length of internodes $(3.74 \mathrm{~cm})$, highest number of fruits per plant (13.73), maximum fruit length $(11.61 \mathrm{~cm})$, highest fruit girth $(3.6$ $\mathrm{cm}$ ), maximum flesh thickness of fruit (7.79 $\mathrm{mm})$, highest fruit weight per plant $(0.82 \mathrm{~kg})$ and maximum fruit yield (17.32 t/ha) which were found to be significantly superior to the other nutrient management treatments barring vine length where FYM + bio-fertilizers $\left(\mathrm{N}_{3}\right)$ treatment demonstrated the maximum length of internodes and was on parity with $\mathrm{N}_{4}$. The least growth, yield variables and yield were obtained with the treatment receiving chemical fertilization at $100 \% \operatorname{RDF}\left(\mathrm{N}_{1}\right)$. The findings clearly suggest that balanced application of nutrients through conjunctive use of readily available inorganic NPK fertilizers, slow release of nutrients and growth promoting substances through organic manure and atmospheric nitrogen fixing biofertilizers like azotobacter and azospirillum might have guaranteed the optimum availability of nutrients in soil throughout the growth stages which in turn encouraged the crop to be more photosynthetically and metabolically active, increases more assimilate production and allocation to fruit that increased the vegetative growth, yield contributing characters and enhanced fruit yield (Tsegaye et al., 2016). On the other hand, application of only chemical fertilizers having quick nutrients releasing characteristics was not sufficient enough to meet the plant nutrition throughout the crop physiological stages resulting in lower growth, yield contributing parameters and yield.

The interaction effect between irrigation and nutrient management showed that highest number of vines per plant (7.17), maximum vine length $(96.49 \mathrm{~cm})$, greatest length of 
internodes $(4.59 \mathrm{~cm})$, highest number of fruits per plant (14.45), maximum fruit length $(12.31 \mathrm{~cm})$, highest fruit girth $(3.77 \mathrm{~cm})$, maximum flesh thickness of fruit $(8.49 \mathrm{~mm})$, highest fruit weight per plant $(0.85 \mathrm{~kg})$ and maximum fruit yield (17.79 t/ha) were found with moderate frequency of irrigation at 10 days interval coupling with 50\% RDF + FYM + bio-fertilizers $\left(\mathrm{I}_{2} \mathrm{~N}_{4}\right)$ which were significantly superior over the remaining irrigation and nutrient treatment combinations.

This was ascribed to the optimum water availability in soil under favourable moderate frequency of irrigation imposed complemented with integrated nutrient management providing readily and slowly available nutrients across the growth stages which might have facilitated better water and nutrients utilization by moderate rooted bitter gourd crop resulting in maximum growth, yield constituents and yield. Conversely, the lowest growth characteristics, yield enhancing parameters and yield were recorded with higher frequency of irrigation supplemented with mineral fertilization with $100 \%$ RDF
$\left(\mathrm{I}_{1} \mathrm{~F}_{1}\right)$. This was probably due to the losses of water and fertilizer nutrients as a result of higher frequency of irrigation adopted which in effect resulted in declined growth, plant parameters and fruit yield.

\section{Seasonal crop water use and water productivity}

The different components of soil water balance, seasonal actual crop water use (ETa) and water productivity (CWP) by bitter gourd under different irrigation frequencies and nutrient management are presented in Table 4. The depth of water applied under irrigation frequency at 7 day interval $\left(\mathrm{I}_{1}\right), 10$ day interval $\left(\mathrm{I}_{2}\right)$ and 15 day interval $\left(\mathrm{I}_{3}\right)$ including a common irrigation of $20 \mathrm{~mm}$ depth was 420 , 320 and $220 \mathrm{~mm}$, respectively. The effective rainfall during the experimental period was $133.7 \mathrm{~mm}$. The soil profile water contribution ranged between 25.5 and $27.0 \mathrm{~mm}$. Thus the seasonal crop water use or, actual crop evapotranspiration (ETa) under irrigation treatment $\mathrm{I}_{1}, \mathrm{I}_{2}$ and $\mathrm{I}_{3}$ was $579.2,479.6$ and $380.7 \mathrm{~mm}$, respectively.

Table.1 Physical and hydro-physical characteristics of the experimental soil

\begin{tabular}{|c|c|c|c|c|c|c|c|c|}
\hline \multirow{2}{*}{$\begin{array}{l}\text { Soil depth } \\
\text { (cm) }\end{array}$} & \multicolumn{3}{|c|}{ Soil texture (\%) } & \multirow{2}{*}{$\begin{array}{c}\text { BD } \\
\left(\mathbf{M g} / \mathrm{m}^{3}\right)\end{array}$} & \multirow{2}{*}{$\begin{array}{c}\mathbf{K s} \\
(\mathbf{c m} / \mathbf{h r})\end{array}$} & \multirow{2}{*}{$\begin{array}{c}\text { Infiltration } \\
(\mathrm{cm} / \mathrm{hr})\end{array}$} & \multirow{2}{*}{$\begin{array}{c}\text { FC } \\
(\%, w / w)\end{array}$} & \multirow{2}{*}{$\begin{array}{c}\mathbf{P W P}(\%, \\
\mathbf{w} / \mathbf{w})\end{array}$} \\
\hline & Sand & Silt & Clay & & & & & \\
\hline 0-15 & 38.65 & 26.10 & 35. & 1.29 & 2.41 & 1.53 & 21.21 & 12.14 \\
\hline $15-30$ & 40.18 & 27.24 & 32.58 & 1.40 & 2.28 & 1.3 & 20. & 11.32 \\
\hline $30-45$ & 43.23 & 24.65 & 30.12 & 1.35 & 2.19 & 1.24 & 23.57 & 10.56 \\
\hline $45-60$ & 51.92 & 23.36 & 24.72 & 1.45 & 2.17 & 1.17 & 19.70 & 9.65 \\
\hline
\end{tabular}

FC: field capacity, PWP: permanent wilting point, BD: bulk density, Ks: hydraulic conductivity

Table.2 Chemical characteristics of the experimental soil

\begin{tabular}{|c|c|c|c|c|c|c|}
\hline $\begin{array}{c}\text { Soil depth } \\
(\mathbf{c m})\end{array}$ & $\begin{array}{c}\mathbf{p}^{\mathbf{H}} \\
(\mathbf{1 : 2 . 5})\end{array}$ & $\begin{array}{c}\mathbf{E C} \\
(\mathbf{d S} / \mathbf{m})\end{array}$ & $\begin{array}{c}\text { Organic C } \\
(\mathbf{g} / \mathbf{k g})\end{array}$ & $\begin{array}{c}\text { Available } \mathbf{N} \\
(\mathbf{k g} / \mathbf{h a})\end{array}$ & $\begin{array}{c}\text { Available } \mathbf{P}_{2} \mathbf{O}_{\mathbf{5}} \\
(\mathbf{k g} / \mathbf{h a})\end{array}$ & $\begin{array}{c}\text { Available } \mathbf{K}_{\mathbf{2}} \mathbf{O} \\
(\mathbf{k g} / \mathbf{h a})\end{array}$ \\
\hline $\mathbf{0 - 1 5}$ & 6.73 & 0.18 & 6.17 & 198.4 & 29.8 & $\mathbf{1 4 6 . 9}$ \\
\hline $\mathbf{1 5 - 3 0}$ & 6.68 & 0.16 & 5.34 & 174.5 & 34.3 & $\mathbf{1 3 8 . 5}$ \\
\hline $\mathbf{3 0 - 4 5}$ & 6.42 & 0.15 & 4.46 & 163.3 & 28.4 & $\mathbf{1 2 6 . 7}$ \\
\hline $\mathbf{4 5 - 6 0}$ & $\mathbf{6 . 3 5}$ & $\mathbf{0 . 1 3}$ & $\mathbf{3 . 8 7}$ & $\mathbf{1 4 3 . 7}$ & $\mathbf{2 3 . 6}$ & $\mathbf{1 1 2 . 2}$ \\
\hline
\end{tabular}


Table.3 Effect of levels of irrigation and nutrient management on growth characteristics, yield components and fruit yield of bitter gourd

\begin{tabular}{|c|c|c|c|c|c|c|c|c|c|c|c|c|c|c|c|c|c|c|}
\hline Treatment & & & $\begin{array}{r}V_{i} \\
\text { len } \\
(\mathbf{c}\end{array}$ & $\begin{array}{l}\text { ne } \\
\text { gth } \\
\text { m) }\end{array}$ & $\begin{array}{l}\text { Le } \\
\text { int }\end{array}$ & $\begin{array}{l}\text { gth of } \\
\text { nodes } \\
\text { m) }\end{array}$ & & & & & & & $\begin{array}{r}\text { F } \\
\text { thi } \\
\text { of } \\
\text { ( }\end{array}$ & $\begin{array}{l}\text { esh } \\
\text { sness } \\
\text { ruit } \\
\text { m) }\end{array}$ & & & & \\
\hline \multicolumn{19}{|c|}{ Irrigation (I) } \\
\hline $\mathbf{I}_{1}$ & \multicolumn{2}{|c|}{4.77} & \multicolumn{2}{|c|}{69.24} & \multicolumn{2}{|c|}{3.11} & \multicolumn{2}{|c|}{12.53} & \multicolumn{2}{|c|}{10.24} & \multicolumn{2}{|c|}{3.22} & \multicolumn{2}{|c|}{6.72} & \multicolumn{2}{|c|}{0.74} & \multicolumn{2}{|c|}{16.29} \\
\hline $\mathbf{I}_{2}$ & \multicolumn{2}{|c|}{6.62} & \multicolumn{2}{|c|}{77.60} & \multicolumn{2}{|c|}{3.61} & \multicolumn{2}{|c|}{13.21} & \multicolumn{2}{|c|}{10.86} & \multicolumn{2}{|c|}{3.37} & \multicolumn{2}{|c|}{7.54} & \multicolumn{2}{|c|}{0.76} & \multicolumn{2}{|c|}{16.94} \\
\hline $\mathbf{I}_{3}$ & \multicolumn{2}{|c|}{5.33} & \multicolumn{2}{|c|}{70.40} & \multicolumn{2}{|c|}{2.99} & \multicolumn{2}{|c|}{12.59} & \multicolumn{2}{|c|}{10.30} & & & & 88 & 0 . & & 16 & \\
\hline $\operatorname{SEm}( \pm)$ & & & 0 . & & & 12 & 0. & & & & & & & 05 & $0 .($ & & 0. & \\
\hline CD (0.05) & & & 1. & & & 46 & 0. & & & & & & & 19 & $0 .($ & & 0. & \\
\hline Nutrient (N & & & & & & & & & & & & & & & & & & \\
\hline $\mathbf{N}_{1}$ & & & 58 & & & .58 & 12 & & & & & & & 20 & 0. & & 15 & \\
\hline $\mathbf{N}_{2}$ & & & 65 & & & 20 & 12 & & & & & & & 68 & 0 . & & 16 & \\
\hline $\mathbf{N}_{3}$ & & & 83 & & & 43 & 12 & & & & & & & 52 & 0 . & & 16 & \\
\hline $\mathbf{N}_{4}$ & & & 81 & & & 74 & 13 & & & & & & & 79 & 0. & & 17 & \\
\hline $\operatorname{SEm}( \pm)$ & & & 0. & & & .11 & 0. & & & & & & & 06 & $0 .($ & & 0. & \\
\hline CD (0.05) & & & 0 . & & & 32 & 0 . & & & & & & & 19 & $0 .($ & & 0. & \\
\hline Interaction & $\times \mathbf{N}$ & & & & & & & & & & & & & & & & & \\
\hline $\mathbf{I}_{1} \mathbf{N}_{1}$ & & & 55 & & & 47 & & & & & & & & 08 & & & & 52 \\
\hline $\mathbf{I}_{\mathbf{1}} \mathbf{N}_{\mathbf{2}}$ & & & 65 & & & 28 & 12 & & & & & & & 40 & & & & 13 \\
\hline $\mathbf{I}_{\mathbf{1}} \mathbf{N}_{\mathbf{3}}$ & & & 77 & & & 74 & 12 & & & & & & & 05 & & & & 42 \\
\hline $\mathbf{I}_{1} \mathbf{N}_{4}$ & & & 78 & & & 96 & 13 & & & & & & & 36 & & & & 10 \\
\hline $\mathbf{I}_{2} \mathbf{N}_{1}$ & & & 64 & 39 & & 87 & 12 & & & & & & & 42 & & & & 13 \\
\hline $\mathbf{I}_{2} \mathbf{N}_{2}$ & & & 69 & 80 & & 38 & 12 & & & & & & & 10 & & & & 45 \\
\hline $\mathbf{I}_{2} \mathbf{N}_{3}$ & & & 79 & 45 & & 63 & 13 & & & & & & & 19 & & & & 42 \\
\hline $\mathbf{I}_{2} \mathbf{N}_{4}$ & & & 96 & 49 & & .59 & 14 & & & & & & & 49 & & & & 79 \\
\hline $\mathbf{I}_{3} \mathbf{N}_{1}$ & & & 55 & 87 & & 42 & & & & & & & & 11 & & & & 59 \\
\hline $\mathbf{I}_{3} \mathbf{N}_{2}$ & & & 60 & 80 & & 97 & & & & & & & & 55 & & & & 30 \\
\hline $\mathbf{I}_{3} \mathbf{N}_{3}$ & & & 94 & 32 & & 94 & & & & & & & & 32 & & & & 62 \\
\hline $\mathbf{I}_{3} \mathbf{N}_{4}$ & & & & 63 & & 67 & & & & & & & & 55 & & & & 10 \\
\hline & & & (I & & (I & $(\mathrm{N} \times \mathrm{I})$ & (I & & (I & & (I & $(\mathrm{N}$ & (I & $(\mathrm{N} \times \mathrm{I}$ & (Ix & $(\mathrm{N}$ & (Ix & \\
\hline & $\begin{array}{c}\times \\
\mathrm{N})\end{array}$ & $\begin{array}{c}\times I \\
\text { ) }\end{array}$ & $\begin{array}{c}\times \\
\mathrm{N})\end{array}$ & $\begin{array}{c}x I \\
\text { ) }\end{array}$ & $\begin{array}{c}\times \\
\text { N) }\end{array}$ & & $\begin{array}{c}\times \\
\mathrm{N})\end{array}$ & $\begin{array}{c}\times I \\
)\end{array}$ & $\begin{array}{c}x \\
N)\end{array}$ & $\begin{array}{c}\times I \\
)\end{array}$ & $\begin{array}{c}\times \\
\mathrm{N})\end{array}$ & $\begin{array}{c}\times I \\
\text { ) }\end{array}$ & $\begin{array}{c}\times \\
\text { N) }\end{array}$ & ) & N) & $\times I)$ & N) & $\times \mathrm{I})$ \\
\hline $\operatorname{SEm}( \pm)$ & 0. & 0. & 0. & 0. & 0. & 0.23 & 0. & 0. & 0 . & 0. & 0. & 0. & 0. & 0.10 & 0.0 & 0.0 & 0.0 & 0.0 \\
\hline CD (0.05) & $\mathrm{N}$ & $\mathrm{N}$ & 1. & 1. & 0 . & 0.62 & 0. & 0. & 0. & 0. & $\mathrm{~N}$ & $\mathrm{~N}$ & 0. & 0.34 & 0.0 & 0.0 & 0.2 & 02 \\
\hline & $\mathrm{S}$ & $\mathrm{S}$ & 70 & 72 & 66 & & 38 & 34 & 33 & 35 & $\mathrm{~S}$ & $\mathrm{~S}$ & 34 & & 13 & 13 & 1 & 3 \\
\hline
\end{tabular}

$\mathrm{I}_{1}:$-day interval, $\mathrm{I}_{2}: 10$-day interval, $\mathrm{I}_{3}: 15$ day interval; $\mathrm{N}_{1}: 100 \% \mathrm{RDF}, \mathrm{N}_{2}: 75 \% \mathrm{RDF}+$ bio-fertilizer, $\mathrm{N}_{3}: \mathrm{FYM} @ 15$ t/ha + bio-fertilizer, $\mathrm{N}_{4}: 50 \%$ RDF + FYM @ 15 t/ha + bio-fertilizer; RDF: 60:40:40 kg NPK/ha 
Table.4 Water balance components, actual crop evapotranspiration (ETa) and crop water productivity (CWP) of summer bitter gourd during 2018

\begin{tabular}{|c|c|c|c|c|c|}
\hline Treatment & $\begin{array}{c}\text { Irrigation } \\
\text { water }(\mathbf{m m})\end{array}$ & $\begin{array}{c}\text { Effective } \\
\text { rainfall }(\mathbf{m m})\end{array}$ & $\begin{array}{c}\text { Profile water } \\
\text { contribution }(\mathbf{m m})\end{array}$ & $\begin{array}{c}\text { ETa } \\
(\mathbf{m m})\end{array}$ & $\begin{array}{r}\text { CWP } \\
\left(\mathrm{kg} / \mathrm{m}^{3}\right)\end{array}$ \\
\hline \multicolumn{6}{|c|}{ Irrigation (I) } \\
\hline$I_{1}$ & 420 & 133.7 & 25.5 & 579.2 & 2.81 \\
\hline $\mathbf{I}_{2}$ & 320 & 133.7 & 25.9 & 479.6 & 3.53 \\
\hline $\mathbf{I}_{3}$ & 220 & 133.7 & 27.0 & 380.7 & 4.31 \\
\hline \multicolumn{6}{|l|}{ Nutrient (N) } \\
\hline$N_{1}$ & 320 & 133.7 & 26.9 & 480.6 & 3.37 \\
\hline $\mathbf{N}_{2}$ & 320 & 133.7 & 26.3 & 480.0 & 3.50 \\
\hline $\mathbf{N}_{3}$ & 320 & 133.7 & 25.9 & 479.6 & 3.61 \\
\hline $\mathbf{N}_{4}$ & 320 & 133.7 & 25.5 & 479.2 & 3.72 \\
\hline \multicolumn{6}{|c|}{ Interaction $(\mathbf{I} \times \mathbf{N})$} \\
\hline $\mathbf{I}_{1} \mathbf{N}_{1}$ & 420 & 133.7 & 26.3 & 580.0 & 2.68 \\
\hline $\mathbf{I}_{1} \mathbf{N}_{2}$ & 420 & 133.7 & 25.7 & 579.4 & 2.78 \\
\hline $\mathbf{I}_{\mathbf{1}} \mathbf{N}_{3}$ & 420 & 133.7 & 25.2 & 578.9 & 2.84 \\
\hline $\mathbf{I}_{1} \mathbf{N}_{4}$ & 420 & 133.7 & 24.9 & 578.6 & 2.96 \\
\hline $\mathbf{I}_{2} \mathbf{N}_{1}$ & 320 & 133.7 & 26.7 & 480.4 & 3.36 \\
\hline $\mathbf{I}_{2} \mathbf{N}_{2}$ & 320 & 133.7 & 26.1 & 479.8 & 3.43 \\
\hline $\mathbf{I}_{2} \mathbf{N}_{3}$ & 320 & 133.7 & 25.6 & 479.3 & 3.63 \\
\hline $\mathbf{I}_{2} \mathbf{N}_{4}$ & 320 & 133.7 & 25.2 & 478.9 & 3.71 \\
\hline $\mathbf{I}_{3} \mathbf{N}_{\mathbf{1}}$ & 220 & 133.7 & 27.6 & 381.3 & 4.09 \\
\hline $\mathbf{I}_{3} \mathbf{N}_{2}$ & 220 & 133.7 & 27.2 & 380.9 & 4.28 \\
\hline $\mathbf{I}_{3} \mathbf{N}_{3}$ & 220 & 133.7 & 26.8 & 380.5 & 4.37 \\
\hline $\mathbf{I}_{3} \mathbf{N}_{4}$ & 220 & 133.7 & 26.3 & 380.0 & 4.50 \\
\hline
\end{tabular}

$\mathrm{I}_{1}: 7$-day interval, $\mathrm{I}_{2}: 10$-day interval, $\mathrm{I}_{3}: 15$ day interval; $\mathrm{N}_{1}: 100 \% \mathrm{RDF}, \mathrm{N}_{2}: 75 \% \mathrm{RDF}+$ biofertilizer, $\mathrm{N}_{3}$ : FYM @ 15 t/ha + bio-fertilizer, $\mathrm{N}_{4}$ : 50\% RDF + FYM @ 15 t/ha + bio-fertilizer; RDF: 60:40:40 kg NPK/ha

Fig.1 Meteorological parameters during the experimental period

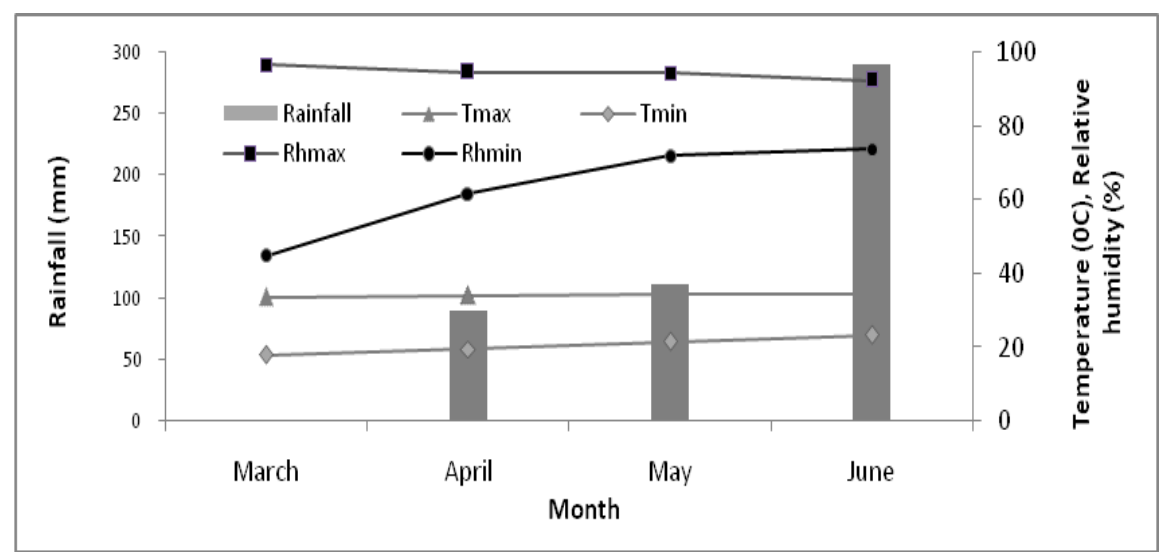


Fig.2 Water-yield relationship for summer bitter gourd

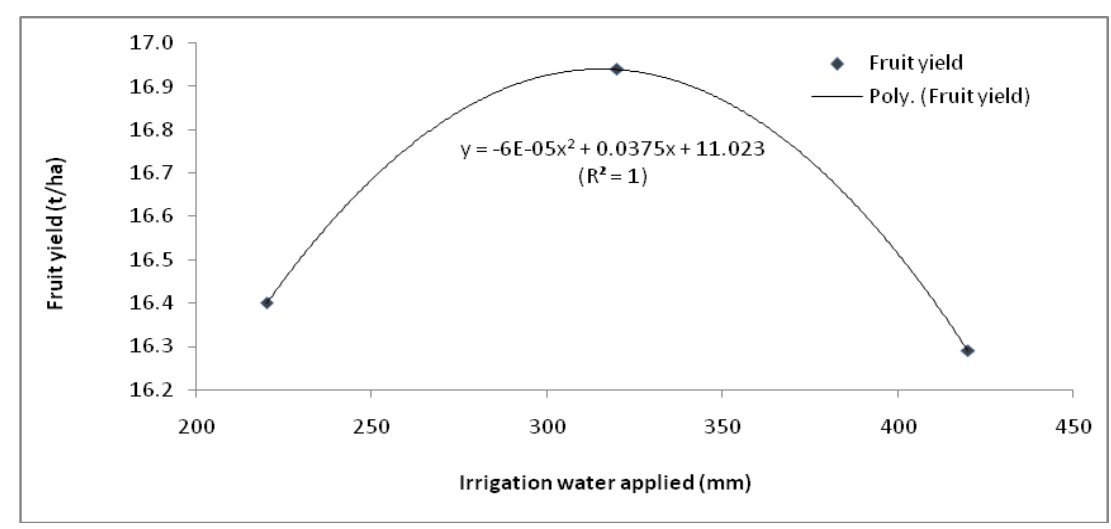

A perusal of the data showed that ETa and CWP were variably influenced by the quantum of water applied, amounts of nutrients added and contributions of water from soil profile and rainfall. Irrespective of different nutrient management, maximum CWP of $4.31 \mathrm{~kg} / \mathrm{m}^{3}$ was found with irrigation frequency at 15 day interval $\left(\mathrm{I}_{3}\right)$ followed by 10 day interval $\left(\mathrm{I}_{2}\right)$ as $3.53 \mathrm{~kg} / \mathrm{m}^{3}$ and 7 day interval $\left(\mathrm{I}_{1}\right)$ as $2.81 \mathrm{~kg} / \mathrm{m}^{3}$, respectively. Likewise, irrespective of irrigation frequencies, higher CWP was exhibited with $50 \% \mathrm{RDF}+\mathrm{FYM}+$ bio-fertilizers $\left(\mathrm{N}_{4}\right)$ as $3.72 \mathrm{~kg} / \mathrm{m}^{3}$ followed by FYM + bio-fertilizers $\left(\mathrm{N}_{3}\right)$ as $3.61 \mathrm{~kg} / \mathrm{m}^{3}, 75 \% \mathrm{RDF}+$ bio-fertilizers $\left(\mathrm{N}_{2}\right)$ as $3.5 \mathrm{~kg} / \mathrm{m}^{3}$ and $100 \% \operatorname{RDF}\left(\mathrm{N}_{1}\right)$ as 3.37 $\mathrm{kg} / \mathrm{m}^{3}$, respectively. The interaction between irrigation and nutrient showed that maximum CWP of $4.5 \mathrm{~kg} / \mathrm{m}^{3}$ was obtained with irrigation frequency at 15 day interval coupling with 50\% RDF + FYM + biofertilizers $\left(\mathrm{I}_{3} \mathrm{~N}_{4}\right)$ which was followed by $\mathrm{I}_{3} \mathrm{~N}_{3}$ as $4.37 \mathrm{~kg} / \mathrm{m}^{3}, \mathrm{I}_{3} \mathrm{~N}_{2}$ as $4.28 \mathrm{~kg} / \mathrm{m}^{3}$ and $\mathrm{I}_{3} \mathrm{~N}_{1}$ as $4.09 \mathrm{~kg} / \mathrm{m}^{3}$. Minimum CWP of $2.68 \mathrm{~kg} / \mathrm{m}^{3}$ was found with irrigation frequency at 7 day interval in association with $100 \% \operatorname{RDF}\left(\mathrm{I}_{1} \mathrm{~N}_{1}\right)$. This indicates that when the crop exposed under excess $\left(\mathrm{I}_{1}\right)$ or deficit $\left(\mathrm{I}_{3}\right)$ irrigation regime with individual or combined application of chemical fertilizers, organic manure and biofertilizers, the CWP was found to be lesser which could be attributed to the losses of water and nutrients in deep percolation, or its unavailability to plants due to frequent soil water stress in different crop growth stages, which eventually did not result in proportionate increase in yield. However, in terms of increased fruit yield and better CWP obtained from irrigation at 10 day interval coupling with $50 \% \mathrm{RDF}+\mathrm{FYM}+$ bio-fertilizers $\left(\mathrm{I}_{2} \mathrm{~N}_{4}\right)$ emerges as a more suitable strategic combination to optimize water and nutrients requirements of crop for maximum yield.

\section{Yield - water production function}

The relationship between fruit yield of bitter gourd (y) and the quantity of irrigation water applied ( $\mathrm{x}$ ) was computed by regression analysis. Fruit yield was taken as dependent variable and plotted against the independent variable ' $x$ ' to derive a mathematical function (Fig. 2). A second degree polynomial equation was best fitted to the data of fresh fruit yield (y) and irrigation water applied (x). The predicted regression equation is given below:

$\mathrm{y}=-0.00006 \mathrm{x}^{2}+0.0375 \mathrm{x}+11.023\left(\mathrm{R}^{2}=\right.$ 1.0)

The variation pattern was validated by the coefficient of determination $\left(\mathrm{R}^{2}\right)$. The $\mathrm{R}^{2}$ value was found to be unity when all the irrigation treatments were considered and was statistically highly significant. In the graph, 
the upward effects indicates the proportional increase in yield with increment of irrigation water applied, while the downward effects displays decline in yield with further increase in water application. This model approach can successfully be used for projecting yield under different supply of irrigation water. Predicted maximum fruit yield of $16.94 \mathrm{t} / \mathrm{ha}$ was estimated at the inflection point of the quadratic regression curve with $320 \mathrm{~mm}$ of irrigation water application which was similar with our experimental findings. The highest reduction in yield by $3.84 \%$ was noticed with irrigation frequency at 7 days interval (420 $\mathrm{mm}$ ) followed by $3.19 \%$ at 15 days interval $(220 \mathrm{~mm})$ as against optimal irrigation frequency at 10 days interval which might have caused negative effect on crop owing to excess as well as deficit soil water regime. This predictive model can also serve as a good guideline for bitter gourd growers in the Indo-Gangetic plains region to yield potential allocation decision related to varying irrigation water supply.

In conclusion it is inferred from the study that moderate frequency of irrigation at 10 days interval along with balanced amounts of nutrients application through 50\% RDF (30:20:20 kg NPK/ha) + FYM @ 15 t/ha + bio-fertilizers (Azotobacter and Azospirillum) inoculation was found to be the best treatment combination for deriving maximum growth characteristics, yield components, fruit yield and moderate water productivity of bitter gourd and may thus be recommended to the Indo-Gangetic plains region of humid subtropical climate.

\section{References}

Acar, B., Paksoy, M., Turkmen, O. and Seymen, M. 2008. Irrigation and nitrogen level affect lettuce yield in greenhouse condition. African J. Biotech., 7(24): 4450-4453.
Ashraf, I., Zain, M., Sarwar, M., Abbasi, K.Y and, Amin, M. 2019. role of different levels of nitrogen, phosphorus and potassium on growth, yield and quality attributes of bitter gourd (Momordica charantia L.). Food Sci. Tech., 7(2): 1621.

Gomez, K.A. and Gomez, A.A. 1984. Statistical Procedures for Agricultural Research. $2^{\text {nd }}$ Edition, John Wiley and Sons, New York, pp 91-115.

Grover, J.K. and Yadav, S.P. 2004 Pharmacological actions and potential uses of Momordica charantia: a review. J. Ethnopharmacology, 39(1): 123-132.

Hari, A.A., and Girija Devi, L. 2016. Studies on fertigation in bitter gourd (Momordica charantia. L.). J. Crop Weed, 12(2): 91-95.

Himanshu, S.K., Singh, A.K., Kumar, S. and Kalura, P. 2013. Response of broccolli to irrigation scheduling and methods under drip, sprinkler and surface irrigation. Int. J. Engg. Adv. Tech., 2(4): 2249-2258.

Kang, S.Z., Shi, W.J. and Zhang, J. 2000. An improved water use efficiency for maize grown under regulated deficit irrigation. Field Crops Res., 67: 207-214.

Kumar, J.L.G. and Senseba, T. 2008. Yield irrigation production efficiency and economic return of broccoli (Brassica oleracea var. italica) under different irrigation method and schedules. J. Environ. Res. Dev., 2(4): 513-522.

Nemeskeri, E. and Helyes, L. 2019. Physiological responses of selected vegetable crop species to water stress. Agronomy, 9(8): 447.

NHB (2018-19). Area and production statistics of horticulture crops for 201819 ( $^{\text {rd }}$ advance estimates). National Horticulture Board, Ministry of Agriculture and Farmers Welfare, Government of India.

Oad, F.C., Buriro, U.A. and Agha, S.K. 2004. 
Effect of organic and inorganic fertilizer application on maize fodder production. Asian J. Plant Sci., 3(3): 375-377.

Rani, K.R. and Mallareddy, A. 2007. Performance of bitter gourd genotypes for yield and earliness. J. Plan. Soil Res., 16:330-333.

Rodríguez, D.N., Cano, R.P., Figueroa, V.U., Palomo, G.A., Esteban, F.C. and Álvarez, R.V. 2008. Producción de tomate en invernadero con humus de lombriz como sustrato. Revista Fitotecnia Mexicana, 3: 265-272.

Samad, A., Bangulzai, F.M., Bibi, Z., Raziq, A., Ishaq, S.M., Ahmed, S., Faisal, S., Bakhsh, L. and Qadir, A. 2019. Growth and yield response of bitter gourd to foliar applied urea under different irrigation levels. Pure Appl. Biol., 8(1): 50-57.

Samman, S., Chow, J.W.Y, Foster, M.J., Ahmad, Z.I., Phuyal, J.L. and Petocz, P. 2008. Fatty acid composition of edible oils derived from certified organic and conventional agricultural methods. Food Chem., 109: 670-674.

Simsek, M., Tonkaz, T., Kacira, M., Comiekcioglu, N. and Dogan, Z. 2005. The effects of different irrigation regimes on cucumber (Cucumbis salivus L.) yield and yield characteristics under open field conditions. Agric. Water Mng., 73: 173-191.
Singh, J., Pandey, U.C. and Kohli, V. P. 1990. Response of vegetable pea to irrigation. J. Veg. Sci., 17: 11-15.

Thriveni, V., Mishra, H.N., Pattanayak, S.K., Sahoo, G.S. and Thomson, T. 2015. Effect of inorganic, organic fertilizers and biofertilizers on growth, flowering, yield and quality attributes of bitter gourd, Momordica charantia L. Int. J. Farm Sci., 5(1): 24-29.

Trivedi, R.V., Wadher, K.J., Taksande, Jayashri B. and Umekar, M.J. 2011. Bitter melon: a bitter body with a sweet soul. Int. J. Res. Ayurveda Pharmacy, 2(2): 443-447.

Tsegaye, B., Bizuayehu, T., Woldemichael, A. and Mohammed, A. 2016. Yield and yield components of onion (Allium cepa L.) as affected by irrigation scheduling and nitrogen fertilization at Hawassa area districts in southern Ethiopia. J. Med. Biol. Sci. Res., 2(2): 15-20.

Wailare, A.T. 2014. Effect of integrated nutrient management on baby corn ( $\mathrm{Zea}$ mays L.) - a review. International Journal of Scientific Research (IJSR), 3(6):2218-2222.

Zimmermann, M.J., Rocha, M. and Yolanda, T. 1988. Bean crop: Factors affecting productivity. Brazilian Association for the presence of potash and phosphate, Piracicaba, Brazil. pp 317-340.

\section{How to cite this article:}

Subam Khawas, Anirban Bhowmik, Ratneswar Ray and Sanmay Kumar Patra. 2020. Effect of Irrigation and Nutrient Management on Growth, Quality, Yield and Water Productivity of Bitter Gourd in Humid Subtropical Climate. Int.J.Curr.Microbiol.App.Sci. 9(09): 1203-1213. doi: https://doi.org/10.20546/ijcmas.2020.909.148 